Sonic Scope: New Approaches to Audiovisual Culture • Issue One

\title{
Sophie Benn - Silent Dreaming
}

Sophie Benn, Sophie Benn

Published on: Oct 06, 2020

License: Creative Commons Attribution 4.0 International License (CC-BY 4.0). 


\section{Silent Dreaming}

Sophie Benn, Case Western Reserve University

For some art forms, collecting objects will only get you so far. For example, dance has a dubious relationship with its physical artefacts. To be sure, there are souvenirs from performances (ticket stubs, playbills, pointe shoes) and the material remnants of productions (costumes, sets, scenarios, stage plans), but these do not record the motions of the dancers, the "stuff" of the art form. Notation is not a major component of the discipline, and it remains a specialised skill that few dancers possess. Video recording helps in the dissemination of dances, but poses its own problems, as it precludes the possibility of a work that is divorced from the bodies of the people who perform it. Because the content of a dance performance can vary greatly between productions, it is difficult to study historical dance as possessing of concrete works at all. 1 Dance flouts the work-concept as music scholars generally understand it, and studying dance affords a new vantage point from which we can examine the idea of material objecthood itself.

In nineteenth-century Europe, romantic ballet's value largely depended on its ephemerality, which enabled it to function on the stage as a stand-in for the supernatural and the ghostly, or of fleeting psychosexual desire. Its mobility in this way could be cast as a particular strength of the art form. For the French poet and theatre critic Théophile Gautier, part of dance's appeal was its lack of semiotic specificity:

[Ballet] is a silent dream experienced in the waking hours, to which one adds one's own words. The audience works on the theme provided by the author or choreographer, and embroiders it with a thousand variations according to its fancy, and this makes ballet at the same time the most material and the most idealized form of spectacle. According to one's outlook, it can be a series of pirouettes and capers of varying grace, or the most ravishing poem - but a poem that has not been committed to words. $\underline{2}$

Gautier connects this indeterminacy to similar qualities in music in a frequently-quoted passage that rests just above the previous statement: "A ballet is a symphony made visible. Gestures, like music notes, have no very precise meaning, and apart from their general significance, can be interpreted by everyone according to individual taste." $\underline{3}$ Such pronouncements on the connections between music and dance provide a promising framework for historical music studies. As scholars of sound, how can we mobilise the aestheticised commonalities between music and dance to create a richer picture of the tensions that have existed between sonic expression and its records? To what extent should we 
attempt to re-inhabit the discourses of ephemerality and immateriality that attend to both of these art forms?

\section{Bibliography}

Théophile Gautier, “Opéra: Griseldis” [February 16, 1848], in Gautier on Dance, translated by Ivor Guest. London: Dance Books, 1989.

\section{Footnotes}

1. Studies of the work-concept are hardly new to dance studies. Two representative works are Jack Anderson "Idealists, Materialists, and the Thirty-Two Fouettés," reprinted in What is Dance?, ed. Roger Copeland and Marshall Cohen (Oxford: Oxford University Press, 1983), 410-419; Frédéric Pouillaude, Unworking Choreography: The Notion of the Work in Dance, trans. Anna Pakes (Oxford: Oxford University Press, 2017). $\subseteq$

2. Théophile Gautier, “Opéra: Griseldis" [February 16, 1848], in Gautier on Dance, trans. Ivor Guest (London: Dance Books, 1989), 189. My emphasis. $\doteq$

3. Ibid. $\doteq$ 